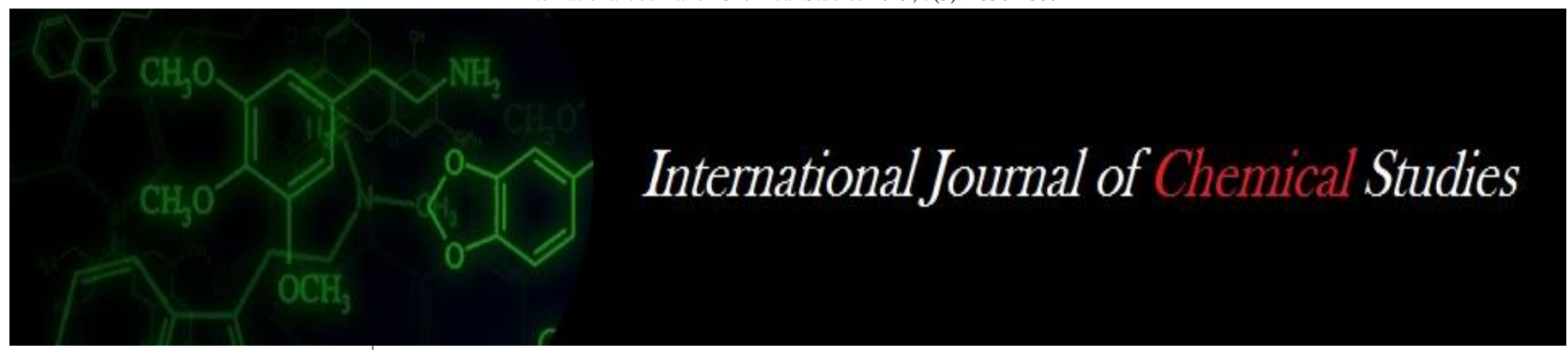

P-ISSN: 2349-8528

E-ISSN: 2321-4902

IJCS 2019; 7(3): 1856-1860

(C) 2019 IJCS

Received: 19-03-2019

Accepted: 21-04-2019

\section{Adarsh S}

PG Scholar, Department of Agronomy, College of

Agriculture, Kerala Agricultural

University, Padannakkad,

Kasaragod, Kerala, India

\section{Giffy Thomas}

PG Scholar, Department of

Agronomy, College of

Agriculture, Kerala Agricultural

University, Padannakkad,

Kasaragod, Kerala, India
Correspondence

Giffy Thomas

PG Scholar, Department of

Agronomy, College of

Agriculture, Kerala Agricultural

University, Padannakkad,

Kasaragod, Kerala, India

\section{Artificial groundwater recharge through rice (Oryza sativa L.) cultivation: A systematic review}

\author{
Adarsh S and Giffy Thomas
}

DOI: https://doi.org/10.22271/chemi.2019.v7.i3.16.07

\begin{abstract}
Rice cultivation aids ground water recharge. Rice requires continuous supply of water through irrigation. Around 60 percent of the irrigation water is used by the plants; remaining 40 percent filters through soil recharging the aquifer below. Yet, this concept was vague in its meaning, which renders its implementation difficult. In this paper, an attempt is made to understand the concept; perspective to its essentiality through structured literature review thus trying to identify the overall ideas associated with the topic. The results from studies using soil water balance approach revealed rice as the best recharge potential crop for fallows, rice and non-rice cropped areas for three cropping seasons. Clays with a little salinity is better to recharge groundwater from irrigated paddy field. Increase in relative humidity with decrease in sunshine hours cause rise in groundwater recharge. Water table rises positively in monsoon counter balanced by lower during winter. Agricultural practices with modified cropping pattern mitigate salinization and water logging issues. Rice water management integrates three-dimensional surface and subsurface groundwater level. Production function approach in valuing groundwater recharge shows that dry season agriculture depends on groundwater. Improved insitu water-saving by System of Rice Intensification (SRI) certifies that field irrigation requirement of SRI was lower than traditional irrigation according to 3-D finite element groundwater model (FEMWATER) studies.
\end{abstract}

Keywords: Rice, irrigation, groundwater recharge, system of rice intensification

\section{Introduction}

Rice is the major staple food for world. Irrigated production systems provide 75 percent of the world's rice supply (Cantrell and Reeves, 2002; Qin et al., 2006). However, there are numerous problems that threaten agriculture to fulfill human needs, including climate change; biodiversity loss; land degradation; depletion and pollution of water resources; rising production costs; decreasing number of farms and, linked with that, poverty and a decrease of the rural population (Beus et al., 1990; Goodland, 1997; Rosset et al., 1997; Thrupp, 2000; Ogaji, 2005; Peters, 2010; Lemke, 2012; Rivera-Ferre, 2013) ${ }^{[8,28,64,48,21,54]}$. Agriculture has become the part and parcel of these issues (Goodland, 1997; Koohafkan et al., 2012) ${ }^{[28]}$. Rice cultivation aids ground water recharge as 60 percent of the irrigation water is used by the plants; remaining 40 percent filters through soil recharging the aquifer below. Yet, this concept even misused and exploited (Constance, 2010) ${ }^{[19]}$. In this review paper, we aim to advance understandings of sustainable agriculture on social processes rather than mapping it as a technical paradigm. A literature review with the objective of identifying the ideas and aspects associated where focused to identify patterns and differences in adoption and application of these ideas. This in turn might benefit future work as every attempt to realize the significance is indispensable (Pretty, 1999; Giovanucci et al., 2012; Matson et al., 1997; Shi et al., 2005; Tilman et al., 2002) ${ }^{[50,44,25,65]}$. Irrigation can mitigate salinization and water logging, in irrigated areas (Zhou et al., 2016; Emna et al., 2016; Singh, 2017a, b). FEMWATER is a three-Dimensional Finite Element Computer Model for simulating subsurface hydrological model for rice cultivation in monsoon region. FEMWATER is developed by Dr. Yeh and Dr. Hsin-Chi (Jerry) Lin to describe flow and transport through saturated-unsaturated porous media using Richards's equation (Lin et al., 1997) ${ }^{[43]}$.

\section{Ground Water}

Water by soil, pores, voids, interstices and crevices in rocks in underground zone of saturation is groundwater. Sub surface flow joins groundwater into surface bodies like rivers, streams. 
Aquifers inside saturated zone store groundwater which can be obtained by extraction and pumping. Rainwater is it's the major source and it replenished within five years so that water table should remain same. Groundwater contributes 50 percent irrigation, 80 percent domestic use in rural areas and 50 percent water for urban and industrial areas. Groundwater is seen as static and dynamic components. Static resources are the aquifers zones below zone of fluctuation which does not replenish annually whereas dynamic resources are replenished annually. The Article 262 of Constitution and National Water Policy of 1987 aimed to limit the utilization of dynamic component and static resources in periods of drought. Annual water availability is predicted by annual aquifer recharge. When mining (over exploitation) of water occurs, it causes for drought or sea water ingress. The potential groundwater reservoirs lie in river basin alluvial formations of Punjab, Haryana, Uttar Pradesh Bihar, West Bengal and Assam. Hard rock formations are seen in south India where wells are used. Groundwater is explored by test drilling, electrical resistivity, electric and gamma ray logging. Net Ground Water Availability \& Ground Water Draft (March 2013) ${ }^{[25]}$ found that annual ground water replenished is $6.84 \mathrm{BCM}$. Artificial Recharge to Ground Water (AR) detailed 4312 check dams, 7181 sub-surface dykes, 10780 gully plugs and 10780 nalah bunds as AR structures with $4650 \mathrm{~km}^{2}$ area with $1078 \mathrm{MCM}$ (million cubic meter) recharged water (Michael, 1978) ${ }^{[45]}$.

\section{Artificial groundwater recharge}

The addition of water to saturation zone expressed in $\mathrm{mm}^{3}$ year $^{-1}$ is recharge. Augmentation of ground water reservoir by natural surface water movement. Artificial recharge addresses issues to enhance aquifer recharge. Aquifers act as "warehouse" for storing water with advantages of being free from inundation of large surface area, loss of cultivable land, displacement of local population, substantial evaporation losses and sensitivity to earthquakes. Aquifers which absorb large quantities of water and release them slowly are ideal that its conductivity is high vertically and low horizontally. Artificial recharge is followed in areas where ground water levels are declining regularly basis with aquifer desaturation or salinity ingress. It has advantages like removal of contaminants by natural cleansing processes and facilitates the water use. Mitigation of the groundwater quality deterioration in shallow coastal aquifers was initiated through groundwater recharge in Cochin (Rajendran, 2002) ${ }^{[52]}$. Local farmers observed that rainfall recharge accounts for about 82 percent of the annual recharge. Bohlke (2002) ${ }^{[10]}$ reported that groundwater recharge effects dissolute aquifer chemical concentrations. Water pumped equals the recharge but not exceeds in surface recharge. It exceeds in deep aquifers where source and sink is distant. Recharge is already more in coastal area to prevent sea water intrusion. In recharge operation, water is made to stand in field or suitable structures can be constructed to divert water to spread water. The main methods include recharging in basin, furrow, ditch, wells or pits. Basin method provides maximum area of recharging with contours preventing water runoff where ground water is irregular. Water from main canal is diverted to parallel shallow flat bottomed furrows in furrow method. Wells and pits are used in areas where the water bearing stratum is overlain by impermeable layer. Water leaches inside topsoil and becomes interflow at impermeable layer and never joins water table. It is usually done in urban areas where large basins can't be made (CGWB, Central Ground Water Board, 2000) ${ }^{[16]}$.

\section{Wetlands}

Wetlands are areas of marsh, fen, peat land or water, whether natural or artificial, permanent or temporary, with water that is static or flowing, fresh, brackish or salty including areas of marine water, the depth of which at low tide does not exceed six meters. It may also incorporate riparian and coastal zones adjacent to the wetlands and islands or bodies of marine water deeper than six meters at low tide lying within the wetland. Centre for Ecological Sciences (2013) stated that wetlands prevent flooding by holding water much like a sponge. They help keep river levels normal and filter and purify the surface water. Wetlands accept water during storms and whenever water levels are high and slowly release water when water levels are low. The richness and usefulness of the wetlands was first brought to the notice of the world by Ramsar Convention on Wetlands in $1971^{[41]}$. Groundwater recharge is considered as main hydrological regulating functions of wetlands. Abraham (2015) found that wetlands have an important influence on the recharge or discharge of groundwater. Groundwater recharge refers to the movement of surface water down through the soil into the zone in which permeable rocks and overlying soil are saturated. Groundwater discharge, in contrast, refers to the movement of groundwater out into the soil surface. Wetland areas where groundwater is discharging are referred as seepage wetlands because they are places where the water seeps slowly out into the soil surface. Kokkal et al. (2008) claimed that Kol, Kuttanad and Pokkali paddy systems are classified under Coastal Wetlands with 1.27 lakh ha. With 157 units under natural and artificial this further highlights the importance of the topic. Kuttanad with major paddy cultivated area of Kerala has unique wetland topography has been included under Ramsar sites by understanding their importance.

\section{Groundwater recharge through rice}

Outflows from paddy field are reused downstream through drainage canals or recharge aquifers has been proven through several studies. (Tuong, 1999 ; Belder et al., 2004; Bouman et al., 2001; Cabangon et al., 2000 ; Guerra et al., 1998; Harnpichitvitaya et al., 2000) ${ }^{[35,7,12]}$. Zulu et al. (1996) ${ }^{[71]}$ confirmed that average drainage water reuse was about 14-15 percent in rice irrigation system. Chieng (2003) claimed that multi-functionality of rice fields to recharge the groundwater and water supply to wetlands from field outflows. Chopra (1997) and Gopikuttan (2004) found that paddy lands perform as feeders of aquifers and retain ground water level of the area. They act as the water reservoirs of the state by recharging ground water. When water moves from wetland down into underground aquifer it becomes cleaner. It may be drawn for human consumption or flow laterally underground until it rises to another wetland. Recharge is also beneficial for flood storage-because the runoff is temporarily stored underground, rather than moving swiftly downstream and overflowing. Paddy fields are not just production centers of food grain but a unique wetland ecosystem that delivers a series of ecological services such as retaining water, helping seepage and recharging groundwater and providing natural drainage paths for flood waters. If the average water level in a paddy field is one foot, one hectare will hold 3 million litre of water. This percolates down and replenishes groundwater. Losing paddy fields and wetlands will threaten the state's water security. M.S. Swaminathan, who headed the National Commission for Farmers says, "The country needs over 100 million tons of rice to meet the demand by 2030 . Therefore, all traditional rice farming systems should be conserved for 
rice cultivation." Paddy fields help to recharge underlying aquifers (Sakthivadivel, 2007) ${ }^{[57]}$. Kaushal (2009) claimed that optimal rainwater conservation is done naturally in paddy fields.

\section{Infiltration, percolation \& puddling}

Infiltration is the movement of water into the soil surface (International Rice Research Institute, 1965). Percolation is the movement of water within the soil matrix by gravity pulling the water downward (Huang et al., 2003). Percolation rate controls infiltration rate. Rate of percolation is controlled by soil grain size. Smaller the grains mean smaller the pores so more the frictional resistance to water and hence less hydraulic conductivity. Low hydraulic conductivity means low infiltration rate. Puddling is the process of working saturated or near saturated soils into mud. It is one of the most basic tasks in irrigated paddy field to control weed growth, increasing nutrient availability. Percolation rate of soil is governed more by the water passage ways it contains (root channels or structural cleavage) than by the character or volume of the pore space (Slateob and Byers, 1931; Bouma, 1978) [11]. Fujihara et al. (2013) and Yamada (2010) [69] reported that the ponding water in the plots disappeared even when puddling was conducted carefully during little rainfall and percolations increased during the later periods of rice growth. Absence of drought stress was found by higher rice yield of non-puddled fields than puddled ones. Bhattacharya (2010) found that surface irrigation increases production during monsoon gaps and non-monsoon period with adequate drainage is assured, that the additional water gets recharged underground. Soil salinity under puddling soils was higher than that without puddling (El-Henawy 2013). Soil bulk density were higher under puddling soil than those without puddling (Saffan, 1975; Adachi, 1990; Aggarwal et al., 1995; Behera et al., 2007; Gorgy, 2010; El-Henawy, 2013) [56, 2, 3, 6, 31]. Values of rice yield without puddling were higher than those under puddling (Elias, 1969; Saffan, 1975; Sharma, 1985; Ebada, 1992; Gorgy, 1995; El-Henawy, 2013) [56, 32, 56]. Puddling is one of the most tedious and expensive agricultural practice which destroys soil aggregates which reduces root growth and distribution (Elias, 1969; Saffan, 1975; Alva and Petersen, 1979; Gorgy, 2010) [56, 32, 56]. Values of soil pH under puddling soils were higher than that without puddling. (Ebada, 1992; Gorgy, 1995) [22 31]. Infiltration rate (IR) was significantly affected by puddling (Gorgy, 2010) ${ }^{[32]}$. Puddling disperses clay-skins aggregates and compresses the subsoil (Grant, 1964).Puddling causes dispersion of soil particles and flocculation which reduce macro pore volume in the compacted, anthropogenic horizon (plough sole or tillage pan) (Adachi and Inoue, 1988; Adachi, 1990 Wopereis, 1993; and Aggarwal et al., 1995) [2]. Puddling lowers soil hydraulic conductivity (DeDatta and Kerim, 1974 Adachi and Inoue, 1988; and Naklang et al., 1996). Puddling decreases water percolation rate under field and laboratory conditions, (Mousavi et al., 2009; Adachi and Inoue, 1988; Wopereis, 1993) [2]. Percolation rate increased rice grain yield by 21percent over no percolation (De Datta, 1981; Sharma et al., 1985). Razavipour et al. (2014) reported the inverse relationship between clay content and percolation in soil. Water moves out of the root zone by uptake through the crop, and through seepage and percolation beyond the root zone which causes recharge (Wicham, 1978) ${ }^{[68]}$. Soil texture has a strong influence on the magnitude of seepage and percolation losses (Wicham, 1978) ${ }^{[68]}$. Increased bulk density reduces percolation losses of water through no puddled soils
(Ghildyal, 1969) ${ }^{[26]}$. Janssen (2010) ${ }^{[39]}$ reported that the results demonstrate that percolation losses increase in the order of continuous soil saturation, continuous flooding, midseason drainage and intermittent irrigation, mid-season drainage and continuous flooding. Derr et al. (1969) reported that the percent silt and coarse fragments of subsoil were positively correlated with percolation rate whereas percent clay was negatively correlated.

\section{Conclusion}

Ground water can be made available sine die only through artificial recharging. Ground water recharging is best done by wetlands. Paddy fields effectively acts as artificial wetlands which not only recharges ground water but also provides food. Puddling in paddy fields should be done optimally to balance the yield and ground water recharge for attaining sustainability in both aspects

\section{References}

1. Abraham S. The relevance of wetland conservation in Kerala. Int. J of Fauna and Biological Stud. 2015; 2(3):01-05.

2. Adachi K. Effects of rice-soil puddling on water percolation. In: Proceeding of the Transactions of the 14th International Congress of Soil Science, Kyoto, Japan, 1990, 146-151.

3. Aggarwal GC, Sidhu AS, Sekhon NK, Sandhu KS, Sur, HS. Puddling and $\mathrm{N}$ management effects on crop response in a rice-wheat cropping system. Soil Till. Res. 1995; 36(3/4):129-139.

4. Alva AK, Ptersen L. Soil Physical properties in relation to rice yield and water consumption under flood and unflood condition. Plant and Soil. 1979; 52:353-363.

5. Baver LD, Gardner WH, Gardner WR. Soil Physics. John Wiley \& Sons. Inc. New York, 4th edition, 1972.

6. Behera BK, Varshney BP, Swain S. Effect of puddling on physical properties of soil and rice yield. Agric. Mech. Asia Afr. Lat. Am. 2007; 38(1):23-28.

7. Belder P, Bouman BAM, Spiertz JHJ, Cabangon R, Guoan L, Quilang EJP, Yuanhua L, Tuong TP. Effect of water and nitrogen management on water use and yield of irrigated rice. Agric. Water Manag. 2004; 65:193-210.

8. Beus CE, Dunlap RE. Conventional Versus Alternative Agriculture: The Paradigmatic Roots of the Debate. Rural Sociol. 1990; 55:590-616.

9. Bhattacharya AK. Artificial ground water recharge with a special reference to India. Int. $J$ of Res. and Revies in Appl. Sci. 2010; 4(2):214-221.

10. Bohlke JK. Groundwater recharge and agricultural contamination. Hydrogeology J. 2002; 10(1):153-179.

11. Bouma J, Dekker LW. A case study on infiltration into dry clay soil I. Morphological Observations. Geoderma. 1978; 20(1):27-40.

12. Bouman BAM, Tuong TP. Field water management to save water and increase its productivity in irrigated lowland rice. Agric. Water Manag. 2001; 49:11-30.

13. Cabangon RJ, Tuong TP. Soil management for water saving during land preparation of cracked rice soils. Soil and Tillage Res. 2000; 56:105-116.

14. Cantrell R, Reeves T. The cereal of the world's poor takes center stage. Sci. 2002, 296:53.

15. Centre for Ecological Sciences. Technical Report 133. Waterscape of Kerala. Centre for Ecological Sciences, Indian Institute of Science, Bangalore, 2013. 
16. CGWB [Central Ground Water Board]. Guide on Artificial Recharge to Ground Water. Central Ground Water Board, New Delhi. 2000, 59p.

17. Chieng S. Water management for rice production and the environment. In Sustainable development of water resources and operation of participatory irrigation organizations. (Hsu, S. K.Ed.). Proceedings of the ICID Asian Regional Workshop, Taipei, November 10-12, 2003. ICID, Taiwan. 2003, 110-118.

18. Chopra K. Econ. Valuation of Biodivers. Study Report, IEG, New Delhi, 1997.

19. Constance DH. Sustainable Agriculture in the United States: A Critical Examination of a Contested Process. Sustainability, 2010; 2:48-72.

20. De Datta SK. Principles and Practices of Rice Production. John Wiley and Sons, New York. 1981, 618.

21. Derr BD, Matelski RP, Petersen GW. Soil Factors Influencing Percolation Test Performance. Soil Sci. Society of Am. J. 1969; 33(6):942-946.

22. Ebada RH. Study of some physical properties in some soils of middle Delta. M. Sc. Thesis, Faculty of Agric. Tanta University, 1992.

23. Elias RS. Rice production and minimum tillage. Outlook on Agriculture. 1969; 6(2):67-70.

24. Fujihara Y, Oda M, Horikawa N, Ogura C. Hydrologic analysis of rain fed rice areas using a simple semidistributed water balance model. Water Resour. Manag. 2011; 25:2061-2080.

25. Fujihara Y, Yamada R, Oda M, Fujii H, Ito O, Kashiwagi J. Effects of puddling on percolation and rice yields in rain fed lowland paddy cultivation: Case study in Khammouane province, Central Laos. Agric. Sci. 2013; 4(8):360-368.

26. Ghildyal BP. Soil compaction. A new system of rice cultivation. Indian Farming. 1969; 19(1):19-22.

27. Giovanucci D, Scherr S, Nierenberg D, Hebebrand C, Shapiro J, Milder J, Wheeler K. Food and Agriculture: The future of sustainability. In: A Strategic Input to the Sustainable Development in the 21st Century (SD21) Project; United Nations: New York, NY, USA, 2012.

28. Goodland R. Environmental sustainability in agriculture: Diet matters. Ecol. Econom. 1997; 23:189-200.

29. Gopikuttan G. Public Housing Schemes for Rural Poor in Kerala: A Critical Study of their Suitability, Discussion Paper No. 49, Kerala Research Programme on Local Level Development, Centre for Development Studies, Thiruvananthapuram, 2002.

30. Gopikuttan G, Kurup KNP. Centre for Development Studies Thiruvananthapuram. Paddy land conversion in kerala an inquiry into Ecological and Economic aspects in a Midland Watershed Region Final Report Kerala Research Programme on Local Level Development 2004. Centre for Development Studies, Thiruvananthapuram, 2004.

31. Gorgy RN. Effect of some agricultural treatments on rice yield and quality. Ph. D. Thesis, Fac. Agric., Kafr ElSheikh, Tanta Univ., Egypt, 1995.

32. Gorgy RN. Effect of different land preparation treatments and planting methods on growth, yield and yield components of three cultivars. J Agric. Res. 2010; $36(3): 259-277$.

33. Grant CJ. Soil characteristics associated with the wet cultivation of rice. In: The Mineral Nutrition of the Rice Plant, Johns Hopkins Press, Baltimore, 1964, 15-28.
34. Guerra LC, Bhuiyan SI, Tuong TP, Barker R. Producing more rice with less water from irrigated systems. SWIM Paper No. 5. International Water Management Institute, P. O. Box 2075, Colombo, Sri Lanka, 1998.

35. Harnpichitvitaya D, Trebuil G, Oberthür T, Pantuwan G, Craig I, Tuong TP, Wade LJ, Suriya-Aruroj D. Identifying recommendations for subsoil compaction and soil management to improve water and nutrient use efficiency in rain fed lowland rice in characterizing and understanding rain fed environments. Proceedings of the international Workshop on Characterizing and Understanding Rainfed Environments' 2000. Tuong, T. P., Kam, S. P., Wade, L., Pandey, S., Bouman, B. A. M., and Hardy, B. (eds.), Bali, Indonesia. Los Baños Philippines, International Rice Research Institute. 1999, 97-110.

36. Hemmat A, Taki O. Comparison of compaction and puddling as pre-planting soil preparation for mechanized rice transplanting in very gravelly calcisols in central Iran. Soil Till. Res. 2003; 70:65-72.

37. Huang HC, Liu CW, Chen SK, Chen JS. Analysis of percolation and seepage through paddy bunds. J Hydro. 2003; 284:13-25.

38. International Rice Research Institute. 1965. Annual report. Los Banos, Philippines. 1964, 335.

39. Janssen M, Lennartz B, Wöhling T. Percolation losses in paddy fields with a dynamic soil structure: model development and applications. Hydrological Processes. 2010; 24(7):813-824.

40. Kaushal MP. Altmetric Articles Groundwater Recharge Technologies. J of Crop Improv. 2009; 23(1):83-93.

41. Kokkal K, Harinarayanan P, Sabu KK. Wetlands of Kerala. In: Sengupta, M., and Dalwani, R. (eds.), Proceedings of Taal 2007: The 12th World Lake Conference, Kerala State Council for Science, Technology and Environment (KSCSTE), Sasthra Bhavan, Pattom, Thiruvananthapuram 695004, Kerala, India. 2008, 1889-1893.

42. Koohafkan P, Altieri MA, Gimenez EH. Green Agriculture: Foundations for biodiverse, resilient and productive agricultural systems. Int. J Agric. Sustain. 2012; 10:61-75.

43. Lin HCJ, Richards DR, Talbot CA, Yeh GTG, Cheng JRR, Cheng HPP, Jones NL. FEMWATER: A ThreeDimensional Finite Element Computer Model for Simulating Density-Dependent Flow and Transport in Variably Saturated Media. Technical report CHL - 97 1997; 12:151p.

44. Matson PA, Parton WJ, Power AG, Swift MJ. Agricultural Intensification and Ecosystem Properties. Science. 1997; 277:504-509.

45. Michael AM. Irrigation Theory and Practice. Vikas Publishing House Private Limited, 1978, 768p.

46. Mousavi SF, Yousefi-Moghadam S, Mostafazadeh-Fard B, Hemmat A, Yazdani MR. Effect of puddling intensity on physical properties of a silty clay soil under laboratory and field conditions. Paddy and Water Environ. 2009; $7(1): 45-54$.

47. Naklang K, Fukai S, Nathabut K. Growth of rice cultivars by direct seeding and transplanting under upland and lowland conditions. Field Crop Res. 1996; 48(2/3):115123.

48. Ogaji J. Sustainable Agriculture in the UK. Environ. Dev. Sustain. 2005; 7:253-270. 
49. Peters KA. Creating a sustainable urban agriculture revolution. J Environ. Law Litig. 2010; 25:203-247.

50. Pretty JN. Sustainable agriculture, people and the resource base: Impacts on food production. Forum Dev. Stud. 1997; 1:7-32.

51. Qin J, Hu F, Zhang B, Wei Z, Li H. Role of straw mulching in non-continuously flooded rice cultivation. Agric. Water Manage. 2006; 83:252-260.

52. Rajendran S, Ajeeb $\mathrm{P}$, Thompson L. Implications of rainwater harvesting in the coastal aquifer - A case study. Proceedings, International conference on water resource and management in arid regions, 2002, 135-143.

53. Razavipour T, Farrokh AR. Measurement of vertical water percolation through different soil textures of paddy field during rice growth season. Int. $\mathbf{J}$ of Advanced Biological and Biomedical Res. 2014; 2(5):1379-1388.

54. Rivera-Ferre M, Ortega-Cerdà M, Baumgärtner J Rethinking Study and Management of Agricultural Systems for Policy Design. Sustainability. 2013; 5:38583875.

55. Rosset PM, Altieri MA. Agro ecology vs. input substitution: A fundamental contradiction of sustainable agriculture. Soc. Natl. Resour. 1997; 10:283-295.

56. Saffan MM. Effect of wet-leveling on some physical properties and root system development of rice in clay soils. M. Sc. Thesis, Faculty of Agric. Tanta University, Egypt, 1975.

57. Sakthivadivel R. The Agricultural Groundwater Revolution: Opportunities and Threat to Development. In: Giordano, M. and Villhoth, K.G. (eds.), CAB International, Chapter. 2007; 10:1-16.

58. Sharma PK. Physical edaphology research in low land rice-based cropping system. IRRI Saturday Seminar, 1985; 22.

59. Sharma PK, De Datta SK. Effect of puddling on soil physical properties and processes. Soil physics and rice. IRRI, Los Banos, 1985, 217-234.

60. Shi T, Gill R. Developing effective policies for the sustainable development of ecological agriculture in China: The case study of Jinshan County with a systems dynamics model. Ecol. Econom. 2005; 53:223-246.

61. Singh A. Water logging and salinity management for sustainable irrigated agriculture. I: Overview, implication and plant response. J Irrig. Drain. Eng. 2017a; 143(9):04017035.

62. Singh A. Water logging and salinity management for sustainable irrigated agriculture. II: Engineering measures and bio-drainage. J Irrig. Drain. Eng. 2017b; 143(9):04017036.

63. Slateob CS, Byers HG. A laboratory study of the field percolation rates of soils. Technical Bulletin No. 1931; 232:1-24.

64. Thrupp LA. Linking Agricultural Biodiversity and Food Security: The Valuable Role of Sustainable Agriculture. Int. Aff. 2000; 76:265-281.

65. Tilman D, Cassman KG, Matson PA, Naylor R, Polasky S. Agricultural sustainability and intensive production practices. Nature. 2002; 418:671-677.

66. Tuong TP. Productive water use in rice production: opportunities and limitations. J of Crop Prod. 1999; 2:241-264.

67. Wopereis MCS. Quantifying the impact of soil and climate variability on rain fed rice production. Ph.D. diss.
Wageningen Agric. Univ., Wageningen, Netherlands, 1993.

68. Wicham TH, Singh VP. Water movement through wet soils and rice. International Rice Research Institute, LosBanos Philippines. 1978, 327-358.

69. Yamada R. Agricultural structure and poverty in rain fed areas of central Laos. J of Agric. Development Studies. 2010; 20:50-57.

70. Zhou Y. Water resources management under dual uncertainties: a factorial fuzzy two-stage stochastic programming approach. Stoch. Environ. Res. Risk Assess. 2016 30:795-811.

71. Zulu G, Toyota M, Misawa S. Characteristics of water reuse and its effects on paddy irrigation system water balance and the rice land ecosystem. Agricultural Water Manag. 1996; 31:269-283. 